\title{
Hand Hygiene in Haemodialysis Units
}

\author{
Ayman Karkar \\ Department of Nephrology, Kanoo Kidney Centre, Dammam Medical Complex, Dammam, KSA \\ Email: aymankarkar@yahoo.com
}

Received 5 August 2016; accepted 18 August 2016; published 22 August 2016

Copyright @ 2016 by author and OALib.

This work is licensed under the Creative Commons Attribution International License (CC BY). http://creativecommons.org/licenses/by/4.0/

(c) () Op Open Access

\begin{abstract}
Healthcare-associated infections are a major risk to patient safety. Infection is the first cause of hospitalisation and the second most common cause of mortality among haemodialysis (HD) patients. HD patients, as well as the dialysis staff, are vulnerable to contracting healthcare-associated infections due to frequent and prolonged exposures to many possible contaminants in the dialysis environment. The extracorporeal nature of the therapy, the associated common environmental conditions, and the immune compromised status of HD patients are major predisposing factors. HD patients are exposed to different types of infections which include bloodstream infections and localized infections of the vascular access, blood-borne infections with hepatitis $B$ virus, hepatitis $C$ virus, and/or human immunodeficiency virus, and airborne infections. Sources of infections include contaminated water, equipment, environmental surfaces, and infected patients. The evident increased potential for transmission of infections in the HD settings led to the creation and implementation of specific and stricter infection prevention and control measures in addition to the usual standard precautions. Contaminated hands of healthcare workers are among the most common modes of transmission of healthcare-associated infections. Hand hygiene is singled out as the most important infection prevention intervention. Hand hygiene compliance can be improved by continuous education and monitoring, providing a sufficient number of sinks with soap dispensers, paper towels, hand lotions and alcohol-based hand rub placed at each patient station, and regular feedback of surveillance results. Education and training and full awareness of infection control policies and procedures should be provided to all Healthcare workers and to be repeated regularly. The patient and/or caregiver should also be educated on hand hygiene and the care of new vascular access.
\end{abstract}

\section{Keywords}

Hand, Hygiene, Haemodialysis, Healthcare, Infection, Vascular Access

Subject Areas: Infectious Diseases, Nephrology

\section{Introduction}

Healthcare-associated infections are a potential risk to patient safety and constitute a major cause of morbidity 
and mortality. In healthcare settings, there are three major types of healthcare-associated infections: surgical-site infections, central-line-associated bloodstream infections, and catheter-associated urinary tract infections. In dialysis units, infection is the first cause of hospitalization and the second most common cause of mortality among haemodialysis (HD) patients after cardiovascular disease [1]-[3]. HD patients are exposed to different types of infections which include bloodstream infections and localized infections of the vascular access (catheters and grafts), blood-borne infections with hepatitis B virus (HBV), hepatitis C virus (HCV), and/or human immunodeficiency virus (HIV), and airborne infections like tuberculosis. Sources of infections could be contaminated water, equipment, environmental surfaces in the treatment area, and patients with infections who pose a risk to other nearby patients being treated in the dialysis unit. The increased risk for contracting healthcare-associated infections (HAIs) among HD patients are mainly due to 1) immune compromised status, 2) frequent and prolonged blood exposure during HD treatments through the vascular access and extracorporeal circuit (with many ports and connections), 3) close proximity to other patients during treatment in the HD facility, 4) frequent contact with healthcare workers who frequently move between patients and between machines, 5) frequent hospitalization and surgery, and most importantly 6) non-adherence or a break in implementation of recommended practices, including hand hygiene and use of personal protective equipment.

The break in implementation of recommended practices may sometimes occur inevitably as a result of one or more of the following factors: 1) understaffing with poor nurse to patient ratio [4]-[6], 2) frequent turn-over of nursing staff [4]-[9], 3) lack of or inadequate training and lower level of competency among HD staff [5] [9][11], 4) inadequate or lack of patient/family education, 5) inadequate provision of necessary supplies/equipment, including adequate clean sinks and/or alcohol-based hand rubs, soap and towels [10] [11], 6) poor design of HD unit lay-out (congested and inadequate segregation/isolation) [11], and 7) the urgency associated with dialysis complications (sometimes life-threatening situation) which may sacrifice adherence to standard precautions [9] [12] [13].

Healthcare Infection Control Practices Advisory Committee (HICPAC) and Centers for Disease Control and Prevention (CDC) recommended two-level approach precautions to prevent the transmission of infectious agents in healthcare settings. These are 1) Standard Precautions and 2) Transmission-Based Precautions. Standard Precautions are the basic level of infection control practices to be applied in the care of all patients and in all healthcare settings, regardless of the suspected or confirmed infection status. Standard Precautions were based on the principle that all blood, body fluids, secretions, excretions (except sweat), non-intact skin, and mucous membranes may contain transmissible infectious agents [14]. The elements of Standard Precautions include: 1) hand hygiene, 2) use of personal protective equipment (PPE) such as gloves, gown, mask, eye protection (eye goggles or face shield), and 3) handling of equipment or items including surfaces in the patient environment in a manner that prevent transmission of infectious agents. CDC added new elements to be considered as a standard of care which include: a) respiratory hygiene/cough etiquette; b) safe injection practices; and c) use of masks for insertion of catheters [14].

Transmission-Based Precautions are usually applied for patients who are known or suspected to be infected or colonized with infectious agents, including certain epidemiologically important pathogens that require additional control measures to effectively prevent transmission. Transmission-Based Precautions have three categories: 1) contact precautions, 2) droplet precautions, and 3) airborne precautions [14].

In addition to Standard Precautions and Transmission-Based Precautions, CDC recommended more stringent measures for HD settings, which include non-sharing of supplies, instruments, medications and medication trays between patients, and prohibit the use of a common medication cart [15]-[18]. Unlike the conditions in general hospital wards, the typical lay-out and associated conditions in most HD units (wherein multiple patients receive extracorporeal treatment with prolonged blood exposures in the same area and usually with one healthcare worker (HCW) caring for more than one patient at the same time) are potential factors that may increase the transmission of infections. Therefore, strict implementation of Standard Precautions and in particular hand hygiene constitutes an essential measure of infection prevention and control. The aim of this narrative review is to mainly focus on hand hygiene and other related Standard Precautions in a HD facility, where the importance of implementation of such precautions is shared with other healthcare settings. Other more specific hemodialysisrelated infection control measures, which include cleaning and disinfection of HD machine's external surfaces, disinfection of internal fluid pathway of HD machines, handling of disposable supplies and reusable items in HD units, purity and testing of treated water, screening and routine serologic testing and patient placement, and immunization of patients and healthcare personnel are all reviewed in [19]. 


\section{Hand Hygiene}

Contaminated hands of HCW are among the most common modes of transmission of healthcare-associated infections. Pittet and colleagues [20] described a five-step sequence resulting in microbial transmission through contaminated hands during healthcare delivery. These are "1) pathogens shed by infected patients can contaminate surrounding environments, 2) HCW's hands get contaminated by contact with patient skin or surrounding environment, 3) pathogen remains viable on the HCW's hands for at least several minutes 4) HCW may omit hand decontamination or use inappropriate product or procedure, and 5) HCW's contaminated hands can either transfer the pathogen directly to another patient or indirectly on a medical device or objects within the patient's immediate vicinity".

Different studies have confirmed that transiently contaminated hands of the HCW are the main route of transmission of healthcare-associated infections [21]-[29]. Hand hygiene, therefore, is singled out as the most important infection prevention intervention. However, the compliance rates of HCWs in hand hygiene is very poor, with an overall average of $40 \%$ or less [30] [31]. Based on hand hygiene indications per recommendations from Association for Professionals in Infection Control and Epidemiology (APIC) [32], CDC [15] and World Health Organization (WHO) [33] (Table 1), the estimated number of times a single dialysis staff is required to perform hand hygiene per HD session per patient is shown in Table 2. The estimated number can be a minimum of 60 to 100 times when multiplied by the number of patients assigned per staff (e.g., 2 - 3 patients). The large number of times an HD staff is required to perform hand hygiene could be a reason for lack of compliance. However, compliance can be improved by continuous education, supervision and monitoring of hand hygiene behaviors, where the latter represents the most effective method in improving performance [34].

Monitoring hand hygiene compliance is crucial and direct observation is the current gold standard method. However, direct observation has several limitations, among which are being labor intensive, small sample size (may cover only $1 \%$ of total hand hygiene activity), and not standardized. A new model device application developed by the Computational Epidemiology Research Group at the University of Iowa (the "iScrub Lite", which is available for free download on the Apple iTunes store for Apple ${ }^{\circledR}$ iPhone or iPod), can facilitate the work of the Infection Preventionist (IP) by recording the observations, which can be loaded to an excel spreadsheet for ready analysis. Advanced technologies, with automated electronic devices and software (Real Time Location System), can monitor the number of hand hygiene activity (10 to 50 thousands per month) in each department, floor or unit, and identify the HCW performing the hand hygiene through badge or wristband detection, with indication of the time of day and day of the week hand hygiene is performed, and even provide feedback/cueing to encourage proper hand hygiene [35].

Compliance can also be improved by providing, in convenient locations, a sufficient number of sinks with

Table 1. Hand hygiene indications as recommended by APIC, CDC, and WHO.

\begin{tabular}{|c|c|c|}
\hline APIC [32] & CDC [15] & $\begin{array}{l}\text { WHO-“My Five Moments for Hand } \\
\text { Hygiene” [33] }\end{array}$ \\
\hline \multirow{2}{*}{ 1. Just before touching a patient } & $\begin{array}{l}\text { 1. Before touching a patient, even if gloves } \\
\text { will be worn }\end{array}$ & 1. Before touching a patient \\
\hline & $\begin{array}{l}\text { 2. Prior to performing an aseptic task (e.g., } \\
\text { placing an IV, preparing an injection) }\end{array}$ & 2. Before clean/aseptic procedure \\
\hline $\begin{array}{l}\text { 2. After touching blood, body fluids, } \\
\text { secretions, excretions and contaminated } \\
\text { items (including front of the HD machine) }\end{array}$ & $\begin{array}{l}\text { 3. After contact with blood, body fluids, } \\
\text { excretions, or wound dressings }\end{array}$ & 3. After body fluid exposure risk \\
\hline \multirow{2}{*}{ 3. Before leaving a patient station } & 4. Before exiting the patient's care area after & 4. After touching a patient \\
\hline & immediate environment & 5. After touching patient surroundings \\
\hline 4. Before accessing or restocking supplies & $\begin{array}{l}\text { 5. If hands will be moving from a } \\
\text { contaminated-body site to a clean-body } \\
\text { site during patient care }\end{array}$ & \\
\hline 5. After gloves are removed & 6. After glove removal & \\
\hline
\end{tabular}

APIC = Association for Professionals in Infection Control and Epidemiology, CDC = Centers for Disease Control and Prevention, WHO = World Health Organization. 
Table 2. Estimated minimum number of times where hand hygiene is required per dialysis session per patient [19] (regardless of gloves use).

\begin{tabular}{|c|c|c|c|c|}
\hline SN & Activity & Before & After & Total \\
\hline 1 & Accessing supplies from common clean storage area & 1 & - & 1 \\
\hline 2 & Preparing/setting-up the HD machine & * & 1 & 1 \\
\hline 3 & Preparing/administering medications (including for anticoagulation) & 1 & 1 & 2 \\
\hline 4 & Pre-dialysis: measuring vital signs/weighing & * & 1 & 1 \\
\hline 5 & Preparing trolley/tray for cannulation & * & 1 & 1 \\
\hline 6 & Palpating clean cannulation sites & * & 1 & 1 \\
\hline 7 & Skin preparation \& cannulation of arteriovenous access (AVF, AVG) & * & 1 & 1 \\
\hline 8 & Preparing trolley for catheter dressing ${ }^{* *}$ & * & 1 & 1 \\
\hline 9 & Removing old dressing over catheter site ${ }^{* *}$ & - & 1 & 1 \\
\hline 10 & Catheter exit site dressing $^{* *}$ & $*$ & 1 & 1 \\
\hline 11 & Connection for HD & 1 & 1 & 2 \\
\hline 12 & Handling blood samples and other specimens & - & 1 & Minimum 1 \\
\hline 13 & Checking blood pressure (every $1 / 2$ - 1 hour for 4 hours) & 1 & 1 & Minimum 8 \\
\hline 14 & Catheter/blood lines manipulation & 1 & 1 & Minimum 2 \\
\hline 15 & Adjusting machine parameters and/or attending machine alarms & - & 1 & Minimum 1 \\
\hline 16 & Attending to patient's incidents/assisting patient & 1 & 1 & Minimum 2 \\
\hline 17 & Prepare trolley for dialysis disconnection & 1 & - & 1 \\
\hline 18 & Disconnection of HD & 1 & 1 & 2 \\
\hline 19 & Post-dialysis: measuring vital signs/weighing & * & 1 & 1 \\
\hline 20 & Cleaning/disinfection of dialysis equipment & * & 1 & 1 \\
\hline 21 & Leaving the dialysis unit & 1 & - & 1 \\
\hline
\end{tabular}

\footnotetext{
* Most of the time, the activity is recently preceded by a hand hygiene performed at the end of one procedure/activity (between two different activities). Therefore, repetition of hand hygiene prior to an activity (wherein performance of hand hygiene is indicated per recommendation) is unnecessary.

${ }^{* *}$ Not included for patients with permanent arteriovenous (AV) access.
}

soap dispensers, paper towels, hand lotions (e.g., one for every 2 - 4 dialysis station), and alcohol-based hand rub (ABHR) placed at each patient station [32]. Because of the proven superior efficacy in decontamination, better skin tolerability and ease of use, ABHR is recommended to be used in all clinical situations if hands are not visibly soiled. If exposure to bacterial spores (i.e., bacillus anthracis and/or clostridium difficile) is suspected or proven, hand washing with soap and water is recommended, because spores are resistant to most antiseptic agents and requires physical removal by washing and rinsing [36]. Other preventive measures include restriction of having long nails and wearing of artificial fingernails or extenders by healthcare personnel who provide direct patient care, as artificial nails could harbor gram negative bacilli and yeasts [30] [32] [36]-[40].

\section{Personal Protective Equipment}

Personal Protective Equipment (PPE) refers to a variety of barriers and respirators used alone or in combination to protect mucous membranes, airways, skin, and clothing from contact with infectious agents, which includes: gloves, gowns, masks, eye goggles, face shields, and respirators [36]. In the HD setting, gloves are recommended to be worn whenever caring for a dialysis patient; whether touching patient's intact skin (e.g., taking blood pressure) or patient's equipment at the dialysis station. Gloves should be removed and followed by hand hygiene between patients or stations [16] [32]. The recommended practice of glove use for every contact with the patient(s) and equipment(s) at the dialysis station requires an enormous amount of glove supply, which is not al- 
ways realistic in many HD units. However, when visible soil is present and/or contact precautions are indicated, wearing gloves is a must. Sterile gloves must be used during procedures requiring sterile aseptic technique, such as during catheter insertion or at any time a dialysis catheter is handled/manipulated [41]-[43]. Wearing gown (fluid-resistant with full coverage of the arms and body front and preferably disposable ones) over the uniform, and use of face mask and eye goggles or face shield is recommended when performing procedures wherein splashes of blood can be anticipated, especially during initiation and discontinuation of dialysis [16] [32] [36]. If a face shield is used during catheter handling, a surgical mask should be worn underneath to protect patient from HCW's respiratory droplets [32]. Equally important is that patient should also wear a mask and asked to turn his/her face away from the catheter site to reduce contamination from infectious droplets [32] [43]-[45]. Furthermore, wearing a mask is important when a staff member, a patient or a visitor is experiencing cold or cough [32] [36]. A respirator should be used by HCWs only when taking care of a patient with an airborne infection. HCWs uniforms can be colonized with potentially pathogenic bacteria for up to 60\% [46]-[51] and therefore should be laundered and changed daily in order to decrease the bacterial load.

\section{Cleaning and Disinfection of Environmental Surfaces}

In the healthcare setting, contamination of environmental surfaces with various pathogens and the persistence of these pathogens on surfaces [52]-[58] can be an important and frequent source of transmission of infectious agents through the frequent hand touching of HCWs [59] [60]. The environment in HD units is particularly prone for contamination with blood-borne pathogens such as HBV, HCV and HIV, and other infectious agents such as methicillin-resistant Staphylococcus aureus (MRSA), vancomycin-resistant Enterococci (VRE), and Clostridium difficile (C. difficile). Microorganisms can survive on environmental surfaces for varying periods of time ranging from few hours to days and months. Low temperature, high humidity and high inoculums favor the long persistence of pathogens on inanimate surfaces [52]. In order to prevent and control spread of environmentally transmitted pathogens, cleaning and disinfection of the external surfaces of equipment (i.e., HD machine, dialysis chair or bed, procedure trolley) and other environmental surfaces inside HD units, especially those that are frequently touched by patients and staff, should be performed between all patient treatments (irrespective of the patient diagnosis) [16] [32] [43]. The application of friction during cleaning is emphasized since some organisms like $C$. difficile are not easily inactivated by most surface disinfectants (except bleach) and require removal by friction [32] [36].

\section{Cleaning and Disinfection of Auxiliary Equipment}

Auxiliary equipment used in HD may include reusable jugs for mixing bicarbonate solution, reusable priming buckets, and external pressure transducers. As per recommendation, any reusable item should be cleaned and disinfected prior to being used on another patient, and external pressure transducers should be changed between patients' uses. Nowadays, many units have shifted to use the more hygienic automated process of mixing bicarbonate powder in cartridge on the individual machines eliminating the use of reusable bicarbonate jugs. If bicarbonate solution in a jug is used, any "left-over" solution must be discarded and opened jugs should not be used after 24 hours because sodium bicarbonate solution substitute a good media for bacterial growth [32]. Reusable priming buckets are now seldom used since most dialysis companies include a disposable prime collection bag in each pack of sterile bloodline set, and also with pre-attached external pressure transducers. With improved and better technology in some latest model of HD machines, prime collection bags or transducer protectors are not even required, because drainage of priming solutions can be done by connecting the bloodline to a drainage port in the machine, and blood pressure sensors are completely non-invasive without using transducer connections and protectors.

\section{Handling of Disposable Supplies and Reusable Items in HD Units}

Both CDC and APIC recommended specific measures which include the following: 1) items taken into an individual patient's HD station should be used only for that patient and be disposed of after use, 2) unused item(s) should be cleaned and disinfected before returning to a common clean area or used on another patient, or be disposed of if it cannot be disinfected, and 3) non-disposable items that cannot be comprehensively cleaned and disinfected (e.g., adhesive tape, cloth-covered blood pressure cuffs) should be dedicated for use on a single pa- 
tient [16] [32]. In reality, allocating a blood pressure cuff for each patient may not be practical as too frequent detachment and re-attachment of the cuff can cause imminent damage to the line connections. Reusable blood pressure cuffs that are covered with waterproof material with smooth surface (instead of cloth-covered cuffs) can be an attractive alternative, as they can be comprehensively cleaned and disinfected between patient uses. There should also be a clear separation for storage and handling of clean supplies and medications from contaminated items (i.e., used supplies/equipment, blood samples, biohazard containers).

\section{Safe Injection Practices}

Aside from the basic principles of aseptic technique, there are specific complementary recommendations for HD published by the CDC and APIC, which include the following: 1) all single-use injectable medications and solutions should be dedicated for use on a single patient and be entered one time only, 2) medications packaged as multi-dose should be assigned to a single patient whenever possible, 3) medication preparation should occur in a clean area away from the patient treatment area, and be delivered separately for each patient, 4) not to carry multi-dose vials from station to station or carry medication vials, syringes, alcohol swabs or supplies in pockets, 5) unused medications or supplies taken to the patient's station should be used only for that patient and should not be returned to a common clean area or used on other patients, 6) not to use common medication carts to deliver medications to patients, and if trays are used to deliver medications to individual patients, they must be cleaned between patients [16] [32] [61]. CDC's full recommendations on safe injection practices are shown in Table 3.

\section{Vascular Access: Care and Prevention of Infection}

Infection rates with tunneled dialysis catheters has been estimated to be 10 times higher than that of arteriovenous fistula (AVF) or AV graft [32], and found to be the leading risk factor of bacteremia in chronic HD patients [62]. The international bodies are in concert with the guidelines that vascular access should be a native AV fistula whenever possible, AV graft as the next preferred option, and the use of catheters to be avoided as much as possible [17] [32] [42]-[45]. Vascular access infection prevention measures unanimously recommended by the international bodies are outlined in Table 4, and varying messages on dialysis catheter recommendations are outlined in Table 5. The relevance of "rubbing and soaking the catheter hub with the cap on with a povidone iodine swab for 3 - 5 minutes before the cap is removed" (as recommended by KDOQI) is understandably to disinfect the outside surface thereby preventing inadvertent contamination of the inner hub and ultimate bloodstream contamination. In the 2011 update of CDC Guidelines for the Prevention of Catheter-Related Infections,

\section{Table 3. Key recommendations on safe injection practices in ambulatory care settings.}

\begin{tabular}{|c|c|}
\hline SN & Recommendations \\
\hline 1 & Use aseptic technique when preparing and administering medications \\
\hline 2 & Cleanse the access diaphragms of medication vials with $70 \%$ alcohol before inserting a device into the vial \\
\hline 3 & $\begin{array}{l}\text { Never administer medications from the same syringe to multiple patients, even if the needle is changed or the injection is } \\
\text { administered through an intervening length of intravenous tubing }\end{array}$ \\
\hline 4 & Do not reuse a syringe to enter a medication vial or solution \\
\hline 5 & $\begin{array}{l}\text { Do not administer medications from single-dose or single-use vials, ampoules, or bags or bottles of intravenous solution to more } \\
\text { than one patient }\end{array}$ \\
\hline 6 & Do not use fluid infusion or administration sets (e.g., intravenous tubing) for more than one patient \\
\hline 7 & $\begin{array}{l}\text { Dedicate multidose vials to a single patient whenever possible. If multidose vials will be used for more than one patient, they } \\
\text { should be restricted to a centralized medication area and should not enter the immediate patient treatment area (e.g., operating } \\
\text { room, patient room/cubicle, patient HD station) }\end{array}$ \\
\hline 8 & Dispose of used syringes and needles at the point of use in a sharps container that is closable, puncture-resistant, and leak-proof \\
\hline 9 & Adhere to "national" requirements for protection of HCW from exposure to blood borne pathogens \\
\hline
\end{tabular}


Table 4. Common recommendations on vascular access infection prevention.

Catheter insertion: (Not addressed in KDOQI 2000/2006 guidelines)

- $\quad$ Avoid the use of femoral veins in adult patients

- $\quad$ Catheters should be inserted under strict aseptic technique

- Maximal barrier precautions (use of mask, cap, sterile gown and sterile gloves by the inserter, and large sterile drape to cover the patient)

Catheter care:

- $\quad$ Only trained dialysis staff should perform catheter dressing changes and catheter manipulations

- $\quad$ The catheter exit-site should be examined for proper position and absence of infection by experienced personnel before accessing the bloodstream at each HD session

- Aseptic technique should be used to prevent contamination of the catheter system

- Use of a surgical mask for staff and patient for all catheter system connect, disconnect, and dressing procedures

- Catheter manipulation should be kept at a minimum

[17] [32] [41]

[17] [32] [41]-[43]

[17] [32] [43]

[17] [32] [43]-[45]

[17] [32] [41] [44] [45]

[17] [32] [41] [43] [44]

[32] [43] [44]

[32] [43] [44]

Skin preparation technique for permanent AV access:

- The patient's access arm should be washed with antimicrobial soap and water prior to skin preparation with antiseptic solution

- $\quad$ To locate and palpate the needle cannulation sites prior to skin preparation

- $\quad$ To cleanse the skin by applying antiseptic solution before cannulation (alcohol-based chlorhexidine, or $10 \%$ povidone iodine solution and/or $70 \%$ alcohol)

KDOQI = Kidney Disease Outcomes Quality Initiative.

scrubbing of the access port with an appropriate antiseptic (chlorhexidine, povidone iodine, an iodophor, or 70\% alcohol) was recommended for needleless intravascular catheter systems [17]. The routine scrubbing of dialysis catheter hubs (after cap removal before accessing, and before replacing a new cap) with an appropriate antiseptic was included as part of a recent CDC' score interventions for dialysis bloodstream infection (BSI) prevention (Table 6) [18]. Dialysis providers are cautioned to avoid introduction of the used antiseptic solution into the bloodstream [63]. In an in vitro study by Salzman et al. [64], the potential for the antiseptic used in cleaning the open catheter hub as well as few strands of cotton fibers to enter the bloodstream (simulated), and the effectiveness of normal saline solution (used as control) to reduce the microbial load at a level greater than $99 \%$ of the total number of microorganisms (suggesting mechanical removal) was demonstrated. The cumulative effect of minute residues of toxic antiseptics and foreign substance that may get into the patient's bloodstream when applied repeatedly on open catheter hubs among chronic HD patients have not, and may not be studied. Therefore, it is prudent to choose a safe and non-toxic solution for cleaning open catheter hubs and to emphasize the application of friction while cleaning (scrubbing not just wiping).

Since HD patients are more immune compromised than other surgical patients, pre-surgical infection prevention measures are recommended, which include: 1) pre-surgical shower/bath with an antiseptic agent such as chlorhexidine, the night before and morning of surgery, 2) if hair removal is necessary, to use clippers instead of razors to prevent infection associated with micro-abrasions resulting from razor use, and 3) avoiding intravenous placements and phlebotomy in the arm where access is to be placed (helps prevent infection and maintains vasculature integrity) [32]. Screening and decolonization for MRSA before an elective surgery may be used as an additional measure.

\section{Tracking Infections}

Surveillance for infections (outcome measures), and monitoring adherence to recommended infection prevention practices (process measures) are important components of an infection prevention program [65]. To enable safety, accurate comparison and analyses of monthly rates within the same facility, or meaningful benchmarking with other units/centers, it is important that a standardized and validated surveillance protocol be used uniformly by all dialysis facilities [66] [67]. A centralized surveillance system for healthcare-associated infections like the CDC's national healthcare safety network (NHSN) which requires all participating facilities to strictly follow very specific surveillance criteria, can provide accurate and reliable data that can be used to identify problem areas as well as measure progress of prevention efforts. Implementation of CDC's NHSN Dialysis Event Protocol (accessible online: www.cdc.gov/nhsn/dialysis) by other dialysis facilities outside the United States have 
Table 5. Varying messages on catheter-related infection prevention strategies.

\begin{tabular}{|c|c|c|c|}
\hline NKF/KDOQI & EBPG/ERBP & APIC & CDC \\
\hline \multicolumn{4}{|c|}{ Chlorhexidine for skin antisepsis } \\
\hline $\begin{array}{l}\text { "Chlorhexidine } 2 \% \text { with } 70 \% \\
\text { alcohol is the preferred solution } \\
\text { for cleansing of long-term } \\
\text { catheter sites. For patients with } \\
\text { sensitivities to chlorhexidine } \\
2 \% \text { with } 70 \% \text { alcohol, } \\
\text { chlorhexidine aqueous may be } \\
\text { used instead. For patients with } \\
\text { sensitivities to chlorhexidine } \\
\text { aqueous, povidone solution } \\
\text { may be used.” [44] }\end{array}$ & $\begin{array}{c}\text { The importance of skin } \\
\text { antisepsis before catheter } \\
\text { placement is indicated } \\
\text { without mention of preferred } \\
\text { antiseptic solution [41] }\end{array}$ & $\begin{array}{l}\text { "For patients older than } 2 \\
\text { months, a skin preparation } \\
\text { solution containing }>0.5 \% \\
\text { chlorhexidine gluconate and } \\
70 \% \text { isopropyl alcohol } \\
\text { should be applied to the } \\
\text { insertion site and allowed to } \\
\text { dry before the skin is } \\
\text { punctured." [32] }\end{array}$ & $\begin{array}{c}\text { "Use an alcohol-based } \\
\text { chlorhexidine (>0.5\%) } \\
\text { solution as the first line skin } \\
\text { antiseptic agent for central } \\
\text { line insertion and during } \\
\text { dressing changes. } \\
\text { Povidone-iodine (preferably } \\
\text { with alcohol) or 70\% alcohol } \\
\text { are alternatives for patients } \\
\text { with chlorhexidine } \\
\text { intolerance" [18] }\end{array}$ \\
\hline
\end{tabular}

Technique for all connect, disconnect, dressing procedures, catheter manipulations

Clean aseptic technique (use of clean gloves) [44]
Sterile aseptic technique (use of sterile materials) [41]
Clean aseptic technique (use of clean gloves) [32]
"Wear either clean or sterile gloves when changing the dressing on intravascular catheters” [17]

\section{Soaking and cleansing the catheter hub connection site with the cap on, with an antiseptic pad/swab}

"Cleanse hub connection site and cap vigorously with the first swab" [44]. "The catheter hub caps or bloodline connectors should be soaked for 3 - 5 minutes in povidone iodine and then allowed to dry prior to separation" [45]

Not mentioned in 2000 Vascular Access Guidelines and in 2006 update [44] [45]

"Changing the catheter exit-site dressing at each HD treatment, using either a transparent dressing or gauze and tape”

[44] "Use of dry gauze

dressing... at the catheter exit-site are recommended after catheter placement and at the end of each dialysis session" [45]
Not mentioned in ERBP 2010 position statement on diagnosis, prevention and treatment of haemodialysis CRBSI, and in 2007/2002 guidelines [41]-[43]
"The hub of HD catheters can be soaked in povidone-iodine solution or wrapped with gauze saturated with povidone-iodine solution for 5 minutes prior to removing the caps" [32]

\section{Not mentioned in CDC/ HICPAC} guidelines/recommendations [16] [17]

\section{Disinfection of catheter hub after cap removal}

Not mentioned in ERBP 2010 position statement on diagnosis, prevention and treatment of haemodialysis CRBSI, in 2007 and 2002 vascular access guidelines [41]-[43]

\section{Catheter exit-site dressing}

"With long-term catheters, The catheter exit-site should be covered by a dressing as long as the catheter remains in place.

The exit-site should be inspected at every HD session, and the exit-site dressing should be replaced on a routine basis if it is no longer clean or intact”

$$
\text { [41] }
$$
gauze is the preferred choice.
"After removing the cap, the hub should be wiped with chlorhexidine, alcohol, or povidone iodine” [32]
"Scrub catheter hubs with an appropriate antiseptic after cap is removed and before accessing. Perform every time catheter is accessed or disconnected” [18]

\section{"Use either sterile gauze or sterile, transparent,} semipermeable dressing. Replace dressings on short-term CVC sites every 2 days for gauze dressings, and every 7 days for transparent dressings. Replace transparent dressings on tunneled or implanted CVC sites no more than once per week (unless the dressing is soiled or loose), until the insertion site has healed" [17]

\section{Application of antimicrobials or antiseptics on the catheter exit-site}

\footnotetext{
“...combined with skin disinfection using povidone iodine ointment or mupirocin ointment at the catheter exit site are recommended after catheter placement and at the end of each

dialysis session" [45]

Not mentioned in 2006 update [44]
}

"The catheter exit-site dressing should be changed session) if gauze/tape, or every 7 days if transparent dressing is used in addition to or soiled" [32]
"Application of antibiotic ointment at the exit-site should be considered after catheter placement until site has healed but should be discontinued after healing” [41]
Recommended routine application of povidone iodine or triple antibiotic ointment at the time of dressing change [32]
"Use povidone iodine antiseptic ointment or bacitracin/gramicidin/polymixin $\mathrm{B}$ ointment at the hemodialysis insertion and at end of each dialysis session only if this ointment does not interact with the material of the HD catheter

per manufacturer's recommendation” [17] catheter exit site after catheter 


\section{Continued}

\begin{tabular}{|c|c|c|c|}
\hline \multicolumn{4}{|c|}{ Antibiotic lock prophylaxis } \\
\hline $\begin{array}{l}\text { No recommendation for routine } \\
\text { prophylactic use [44] [45] }\end{array}$ & $\begin{array}{l}\text { Preventive use is advocated to } \\
\text { reduce the risk of CRBSI, but } \\
\text { with caution to balance the } \\
\text { benefits against the associated } \\
\text { risk, and should not replace } \\
\text { hygienic standards with } \\
\text { regard to catheter } \\
\text { care and handling [41] }\end{array}$ & $\begin{array}{c}\text { Prophylactic use of } \\
\text { antimicrobial catheter } \\
\text { locking solution as a } \\
\text { "plus measure"-unresolved } \\
\text { issue [32] }\end{array}$ & $\begin{array}{l}\text { "Use prophylactic antimicrobial } \\
\text { lock solution in patients with } \\
\text { long term catheters who have a } \\
\text { history of multiple CRBSI } \\
\text { despite optimal maximal } \\
\text { adherence to aseptic } \\
\text { technique" [17] }\end{array}$ \\
\hline
\end{tabular}

KDOQI = Kidney Disease Outcomes Quality Initiative, EBPG/ERBP = European Best Practice Guidelines/European Renal Best Practice, APIC = Association for Professionals in Infection Control and Epidemiology, CDC/HICPAC = Centers for Disease Control and Prevention/Healthcare Infection Control Practices Advisory Committee.

\section{Table 6. The CDC core interventions for dialysis bloodstream infection (BSI) prevention.}

\section{Surveillance and feedback using NHSN}

1 Conduct monthly surveillance for BSIs and other dialysis events using CDC's National Healthcare Safety Network (NHSN). Calculate facility rates and compare with rates in other NHSN facilities. Actively share results with frontline clinical staff.

2 Hand hygiene observations

Perform observations of hand hygiene opportunities monthly and share results with clinical staff.

\section{Catheter/vascular access care observations}

3 Perform observations of vascular access care and catheter accessing quarterly. Assess staff adherence to aseptic technique when connecting and disconnecting catheters and during dressing changes. Share results with clinical staff.

\section{Staff education and competency}

4 Train staff on infection control topics, including access care and aseptic technique. Perform competency evaluation for skills such as catheter care and accessing upon hire and every 6 - 12 months.

\section{Patient education/ engagement}

5 Provide standardized education to all patients on infection prevention topics including vascular access care, hand hygiene, risks related to catheter use, recognizing signs of infection, and instructions for access management when away from the dialysis unit.

\section{Catheter reduction}

6 Incorporate efforts (e.g., through patient education, vascular access coordinator) to reduce catheters by identifying and addressing barriers to permanent vascular access placement and catheter removal.

\section{Chlorhexidine for skin antisepsis}

$7 \quad$ Use an alcohol-based chlorhexidine (>0.5\%) solution as the first-line skin antiseptic agent for central line insertion and during dressing changes. ${ }^{\circledR}$

\section{Catheter hub disinfection}

8 Scrub catheter hubs with an appropriate antiseptic after cap removal and before accessing. Perform every time catheter is accessed or disconnected.

\section{Antimicrobial ointment}

Apply antibiotic ointment or povidone-iodine ointment to catheter exit sites during dressing change. ${ }^{c}$

${ }^{\mathrm{a}}$ Povidone-iodine (preferably with alcohol) or $70 \%$ alcohol by itself are alternatives for patients with chlorhexidine intolerance. ${ }^{\mathrm{b}}$ If closed needleless connector device is used, disinfect connector device as per manufacturer's instructions. 'See information on selecting an antimicrobial ointment for hemodialysis catheter exit sites on CDC website. Use of chlorhexidine-impregnated sponge dressing might be an alternative. Adapted from CDC. CDC Approach to BSI Prevention in Dialysis Facilities (i.e., the Core Interventions for Dialysis Bloodstream Infection (BSI) Prevention [18].

been demonstrated to be feasible. Dialysis Events that should be reported include: 1) intravenous antimicrobial starts, 2) positive blood cultures, and 3) evidence of local access site infection (pus, redness, or increased swelling at the vascular access site), and data collected from these three events can generate four other types of Dialysis Events: bloodstream infection (BSI), local access site infection (LASI), access-related bloodstream infection (ARB), and vascular access infection (VAI). The number of maintenance HD outpatients who received HD in the unit/center during the first two working days of the month (including transient HD patients but excluding inpatients and peritoneal dialysis patients) should be reported on monthly basis and according to their vascular access type. This will serve as the denominators for rate calculation. Each patient is counted only once; if the patient has multiple vascular accesses, that patient is counted with the vascular access type of highest infection 
risk. Rates are calculated by dividing the number of events by the number of patient-months and multiplying the result by 100 [68].

As a means to reduce infection transmission, each dialysis facility should also monitor other parameters like dialysis water and dialysis fluid cultures and endotoxin results, incidence of drug-resistant infections, hospitalizations, as well adherence to Standard Precautions (hand hygiene, glove use and other PPE, equipment and environmental cleaning, safe injection practices, etc.), and other recommended practices (screening for HBV, HCV, HIV and tuberculosis infections, and immunizations) [19]. Regular feedback of surveillance results to everyone involved in the healthcare delivery (especially the frontline staff) would help to stimulate and encourage active engagement and improve compliance with infection prevention efforts. At least one designated person with training in infection control and epidemiology (infection preventionist) should be responsible for oversight of the program as well as education of staff and patients related to infection prevention and control [15] [32].

Steps that should be taken to control spread of infection, especially if there is an incidence of a positive seroconversion or outbreak in the HD unit, include the following: 1) revision of the laboratory test results of all patients dialyzing in the same unit to identify any additional case(s), 2) performance of additional testing as indicated in Table 7,3) determination/tracking of potential sources for infection, which includes a) revision of newly infected patients' recent history of blood transfusion, invasive procedure(s) and/or hospitalization, and b) high risk behavior such as history of injection drug use and sexual activity, and 4) revision of HD unit's practices and procedures of infection control [16].

\section{Staff and Patient/Family Education}

Education and training in infection prevention and control should be provided to all HCWs upon hire and to be repeated regularly (at least once yearly). Basic principles and practices, including hand hygiene and wearing PPE, for preventing the spread of infections should be covered and monitored, and staff competencies should be assessed and documented upon orientation to the facility and to be repeated as appropriate for the specific staff and position [15] [69]. The patient(s) and/or caregiver(s) should also be educated on hand hygiene and the care of new vascular access and whenever there is a change in access type and repeated at least every year [70] [71]. Key areas for patient education as outlined by CDC are shown in Table 8.

Table 7. Additional testing to be performed in case of positive seroconversions.

\begin{tabular}{|c|c|}
\hline HBsAg Seroconversions [16] & Anti-HCV Seroconversions [72] \\
\hline $\begin{array}{l}\text { In patients newly infected with } \mathrm{HBV}, \mathrm{HBs} A g \text { is the only serologic } \\
\text { marker initially detected. } \\
\text { - } 1 \text { - } 2 \text { months later: repeat HBsAg testing and test for anti-HBc } \\
\text { (including IgM anti-HBc) } \\
\text { - } 6 \text { months later: repeat HBsAg testing and test for anti-HBs }\end{array}$ & $\begin{array}{l}\text { - If a new HCV infection in a hemodialysis unit is suspected to } \\
\text { be nosocomial, testing with NAT should be performed in all } \\
\text { patients who may have been exposed. } \\
\text { - Repeat testing with NAT is suggested within } 2 \text { - } 12 \text { weeks in } \\
\text { initially NAT-negative patients }\end{array}$ \\
\hline
\end{tabular}

Content source: 2001 CDC recommendations for preventing transmission of infections among chronic haemodialysis patients [35], and 2008 KDIGO clinical practice guidelines for the prevention, diagnosis, evaluation and treatment of hepatitis c in chronic kidney disease [72]. HBsAg: Hepatitis B surface Antigen; HCV: Hepatitis C Virus; NAT: Nucleic Acid Amplification.

Table 8. Key areas for patient education.

\begin{tabular}{|c|c|c|c|}
\hline \multicolumn{2}{|r|}{ Patients with Catheters } & \multicolumn{2}{|r|}{ Patients with Permanent AV Access } \\
\hline 1 & Hand hygiene & 1 & Hand hygiene \\
\hline 2 & General access care at home (e.g., bathing with a catheter) & 2 & Washing the access site prior to treatment \\
\hline 3 & Signs and symptoms of infection & 3 & $\begin{array}{l}\text { General access care at home } \\
\text { (e.g., don't scratch or pick at the site) }\end{array}$ \\
\hline 4 & $\begin{array}{l}\text { How to respond if problems with } \\
\text { catheter develop outside of the dialysis center }\end{array}$ & 4 & Signs and symptoms of infection \\
\hline 5 & $\begin{array}{l}\text { Risks associated with } \\
\text { catheters/importance of permanent access }\end{array}$ & 5 & $\begin{array}{l}\text { How to respond if problems with } \\
\text { access develop outside of the dialysis center }\end{array}$ \\
\hline 6 & $\begin{array}{l}\text { Basic infection control practices during } \\
\text { catheter accessing process (as a means to engage patients) }\end{array}$ & 6 & $\begin{array}{l}\text { Basic infection control practices during } \\
\text { cannulation process (as a means to engage patients) }\end{array}$ \\
\hline
\end{tabular}

Content source: Centers for Disease Control and Prevention (CDC), National Center for Emerging and Zoonotic Infectious Diseases (NCEZID), Division of Healthcare Quality Promotion (DHQP) [70]. 


\section{Conclusion}

Contaminated hands of healthcare workers are among the most common modes of transmission of healthcare-associated infections. Hand hygiene is singled out as the most important infection prevention intervention. Compliance can be improved by continuous education, supervision and monitoring of hand hygiene behaviors, providing, in convenient locations, a sufficient number of sinks with soap dispensers, paper towels, hand lotions, and alcohol-based hand rub placed at each patient station. Equally important is the adherence to other Standard Precautions including glove and other PPE use, equipment and environmental cleaning, and safe injection practices, as well as other recommended practices of screening for HBV, HCV, HIV, tuberculosis infections, and immunizations. Regular feedback of surveillance results and steps taken to control spread of infection to everyone involved in the healthcare delivery would help to stimulate and encourage active engagement and improve compliance with infection prevention efforts. Education and training and full awareness of infection control policies and procedures should be provided to all HCWs and to be repeated regularly. The patient and/or caregiver should also be educated on hand hygiene and the care of new vascular access. Finally, implementation of evidence-based international guidelines is of great value and instrumental in helping reduce healthcare-associated infections, where patient's safety and well-being remain a top priority.

\section{Conflict of Interest}

No conflict of interest.

\section{References}

[1] Rayner, H.C., Pisoni, R.L., Bommer, J., Canaud, B., Hecking, E., Locatelli, F., Piera, L., Bragg-Gresham, J.L., Feldman, H.I., Goodkin, D.A., Gillespie, B., Wolfe, R.A., Held, P.J. and Port, F.K. (2004) Mortality and Hospitalization in Haemodialysis Patients in Five European Countries: Results from the Dialysis Outcomes and Practice Patterns Study (DOPPS). Nephrology Dialysis Transplantation, 19, 108-120. http://dx.doi.org/10.1093/ndt/gfg483

[2] Dalrymple, L.S., Johansen, K.L., Chertow, G.M., Cheng, S.C., Grimes, B., Gold, E.B. and Kaysen, G.A. (2010) Infection-Related Hospitalizations in Older Patients with ESRD. American Journal of Kidney Diseases, 56, 522-530. http://dx.doi.org/10.1053/j.ajkd.2010.04.016

[3] Lafrance, J., Rahme, E., Iqbal, S., Leblanc, M., Pichette, V., Elftouh, N. and Vallee, M. (2013) Magnitude of Discordance between Registry Data and Death Certificate When Evaluating Leading Causes of Death in Dialysis Patients. BMC Medical Research Methodology, 13, 51. http://dx.doi.org/10.1186/1471-2288-13-51

[4] Fridkin, S.K., Pear, S.M., Williamson, T.H., Galgiani, J.N. and Jarvis, W.R. (1996) The Role of Understaffing in Central Venous Catheter-Associated Bloodstream Infections. Infection Control and Hospital Epidemiology, 17, $150-158$. http://dx.doi.org/10.2307/30142373

[5] Vicca, A.F. (1999) Nursing Staff Workload as a Determinant of Methicillin-Resistant Staphylococcus aureus Spread in an Adult Intensive Therapy Unit. Journal of Hospital Infection, 43, 109-113. http://dx.doi.org/10.1053/jhin.1999.0246

[6] Harbarth, S., Sudre, P., Dharan, S., Cadenas, M. and Pittet, D. (1999) Outbreak of Enterobacter cloacae Related to Understaffing, Overcrowding, and Poor Hygiene Practices. Infection Control and Hospital Epidemiology, 20, 598-603. http://dx.doi.org/10.1086/501677

[7] Arenas, M.D., Sanchez-Paya, J., Barril, G., Garcia-Valdecasas, J., Gorriz, J.L., Soriano, A., et al. (2005) A Multicentric Survey of the Practice of Hand Hygiene in Haemodialsis Units: Factors Affecting Compliance. Nephrology Dialysis Transplantation, 20, 1164-1171. http://dx.doi.org/10.1093/ndt/gfh759

[8] Cimiotti, J.P., Aiken, L.H., Sloane, D.M. and Wu, E.S. (2012) Nurse Staffing, Burnout, and Healthcare-Associated Infection. American Journal of Infection Control, 40, 486-490. http://dx.doi.org/10.1016/j.ajic.2012.02.029

[9] Efstathiou, G., Papastavrou, E., Raftopoulos, V. and Merkouris, A. (2011) Factors Influencing Nurses’ Compliance with Standard Precautions in Order to Avoid Occupational Exposure to Microorganisms: A Focus Group Study. BMC Nursing, 10, 1. http://dx.doi.org/10.1186/1472-6955-10-1

[10] Sax, H., Perneger, T., Hugonnet, S., Herrault, P., Chraiti, M.N. and Pittet, D. (2005) Knowledge of Standard and Isolation Precautions in a Large Teaching Hospital. Infection Control and Hospital Epidemiology, 26, 298-304. http://dx.doi.org/10.1086/502543

[11] Oliveira, A.C., Cardoso, C.S. and Mascarenhas, D. (2010) Contact Precautions in Intensive Care Units: Facilitating and Inhibiting Factors for Professionals’ Adherence. Revista da Escola de Enfermagem da USP, 44, 161-165. http://dx.doi.org/10.1590/S0080-62342010000100023

[12] Madan, A., Raafat, A., Hunt, J., Rentz, D., Wahle, M. and Flint, L. (2002) Barrier Precautions in Trauma: Is Know- 
ledge Enough? The Journal of Trauma Injury, Infection and Critical Care, 52, 540-543.

http://dx.doi.org/10.1097/00005373-200203000-00020

[13] Kelen, G.D., DiGiovanna, T.A., Celentano, D.D., Kalainov, D., Bisson, L., Junkins, E., Stein, A., Lofy, L., Scott, C.R. and Silvertson, K.J. (1990) Adherence to Universal (Barrier) Precautions during Interventions on Critically Ill and Injured Emergency Department Patients. Journal of Acquired Immune Deficiency Syndromes, 3, 987-994.

[14] Pittet, D., Dharan, S., Touveneau, S., Sauvan, V. and Perneger, T.V. (1999) Bacterial Contamination of the Hands of Hospital Staff during Routine Patient Care. Archives of Internal Medicine, 159, 821-826. http://dx.doi.org/10.1001/archinte.159.8.821

[15] CDC (2011) Guide to Infection Prevention for Outpatient Settings: Minimum Expectations for Safe Care. http://www.cdc.gov/HAI/pdfs/guidelines/standards-of-ambulatory-care-7-2011

[16] CDC (2001) Recommendations for Preventing Transmission of Infections among Chronic Hemodialysis Patients. Morbidity and Mortality Weekly Report, 50, 1-43.

[17] O’Grady, N.P., et al. and the Healthcare Infection Control Practices Advisory Committee (HICPAC) (2011) Guidelines for the Prevention of Intravascular Catheter-Related Infections, 2011. Centers for Disease Control and Prevention (CDC), Atlanta, 83 p.

[18] CDC (2013) CDC Approach to BSI Prevention in Dialysis Facilities I.E., the Core Interventions for Dialysis Bloodstream Infection (BSI) Prevention. https://www.cdc.gov/dialysis/PDFs/Dialysis-Core-Interventions-5_10_13.pdf

[19] Karkar, A., Mandin Bouhaha, B. and Dammang, M.L. (2014) Infection Control in Hemodialysis Units: A Quick Access to Essential Elements. Saudi Journal of Kidney Diseases and Transplantation, 25, 496-519. http://dx.doi.org/10.4103/1319-2442.132150

[20] Pittet, D., Allegranzi, B., Sax, H., Dharan, S., Lúcia Pessoa-Silva, C., Donaldson, L. and Boyce, J.M. (2006) Evidence-Based Model for Hand Transmission during Patient Care and Role of Improved Practices. On Behalf of the WHO Global Patient Safety Challenge and World Alliance for Patient Safety. The Lancet Infectious Diseases, 6, 641652. http://dx.doi.org/10.1016/S1473-3099(06)70600-4

[21] Bauer, T.M., Ofner, E., Just, H.M., Just, H. and Daschner, F. (1990) An Epidemiological Study Assessing the Relative Importance of Airborne and Direct Contact Transmission of Microorganisms in a Medical Intensive Care Unit. Journal of Hospital Infection, 15, 301-309. http://dx.doi.org/10.1016/0195-6701(90)90087-5

[22] Pittet, D. (2001) Improving Adherence to Hand Hygiene Practice: A Multidisciplinary Approach. Emerging Infectious Diseases, 7, 234-240. http://dx.doi.org/10.3201/eid0702.010217

[23] Bhalla, A., Pultz, N.J., Gries, D.M., et al. (2004) Acquisition of Nosocomial Pathogens on Hands after Contact with Environmental Surfaces near Hospitalized Patients. Infection Control and Hospital Epidemiology, 25, 164-167. http://dx.doi.org/10.1086/502369

[24] Larson, E.A. (1988) Causal Link between Hand Washing and Risk of Infection? Examination of the Evidence. Infection Control and Hospital Epidemiology, 9, 28-29. http://dx.doi.org/10.2307/30144131

[25] Farrington, M., Ling, J., Ling, T. and French, G.L. (1990) Outbreaks of Infection with Methicillin-Resistant Staphylococcus aureus on Neonatal and Burn Units of a New Hospital. Epidemiology and Infection, 105, 215-228. http://dx.doi.org/10.1017/S0950268800047828

[26] Gould, D. (1991) Nurses’ Hands as Vectors of Hospital-Acquired Infection: A Review. Journal of Advanced Nursing, 16, 1216-1225. http://dx.doi.org/10.1111/j.1365-2648.1991.tb01531.x

[27] Duckro, A.N., Blom, D.W., Lyle, E.A., Weinstein, R.A. and Hayden, M.K. (2005) Transfer of Vancomycin-Resistant Enterococci via Healthcare Worker Hands. Archives of Internal Medicine, 165, 302-307. http://dx.doi.org/10.1001/archinte.165.3.302

[28] Shimokura, G., Weber, D.J., Miller, W.C., Wurtzel, H. and Alter, M.J. (2006) Factors Associated with Personal Protection Equipment Use and Hand Hygiene among Hemodialysis Staff. American Journal of Infection Control, 34, $100-$ 107. http://dx.doi.org/10.1016/j.ajic.2005.08.012

[29] Kampf, G. and Kramer, A. (2004) Epidemiologic Background of Hand Hygiene and Evaluation of the Most Important Agents for Scrubs and Rubs. Clinical Microbiology Reviews, 17, 863-893. http://dx.doi.org/10.1128/CMR.17.4.863-893.2004

[30] Boyce, J.M. and Pittet, D. (2002) Guideline for Hand Hygiene in Health-Care Settings: Recommendations of the Healthcare Infection Control Practices Advisory Committee and the HICPAC/SHEA/APIC/IDSA Hand Hygiene Task Force. Morbidity and Mortality Weekly Report, 51, 1-44.

[31] Arenas, D., Sanchez-Paya, J., Barril, G., García-Valdecasas, J., Gorriz, J.L., Soriano, A., Antolin, A., Lacueva, J., Garcia, S., Sirvent, A., Espinosa, A. and Angoso, M. (2005) A Multicentric Survey of the Practice of Hand Hygiene in Haemodialysis Units: Factors Affecting Compliance. Nephrology Dialysis Transplantation, 20, 1164-1171. http://dx.doi.org/10.1093/ndt/gfh759 
[32] APIC (2010) Guide to the Elimination of Infections in Hemodialysis. http://www.infectioncontroltoday.com/news/2010/06/apic-introduces-guide-to-elimination-of-infection.aspx

[33] WHO (2016) Save Lives: Clean Your Hands. Hand Hygiene in Outpatient and Home-Based Care and Long-Term Care Facilities. A Guide to the Application of the WHO Multimodal Hand Hygiene Improvement and the "My Five Moments of Hand Hygiene” Approach. WHO Library Catologuing-in-Publication Data. http://www.who.int/gpsc/5may/EN_PSP_GPSC1_5May_2016/en/

[34] Allegranzi, B., Gayet-Ageron, A., Damani, N., Bengaly, L., McLaws, M.L., Moro, M.L., Memish, Z., Urroz, O., Richet, H., Storr, J., Donaldson, L. and Pittet, D. (2013) Global Implementation of WHO’s Multimodal Strategy for Improvement of Hand Hygiene: A Quasi-Experimental Study. The Lancet Infectious Diseases, 13, 843-851. http://dx.doi.org/10.1016/S1473-3099(13)70163-4

[35] Hedderwick, S.A., McNeil, S.A., Lyons, M.J. and Kauffman, C.A. (2000) Pathogenic Organisms Associated with Artificial Fingernails Worn by Healthcare Workers. Infection Control and Hospital Epidemiology, 21, 505-509. http://dx.doi.org/10.1086/501794

[36] Siegel, J.D., Rhinehart, E., Jackson, M., Chiarello, L. and the Healthcare Infection Control Practices Advisory Committee (2007) Guidelines for Isolation Precautions: Preventing Transmission of Infectious Agents in Healthcare Settings. http://www.cdc.gov/ncidod/dhqp/pdf/isolation2007.pdf

[37] Infection Control Today (ICT) (2013) Challenges and Solutions for Measuring Hand Hygiene Compliance. On-Demand Webinar.

[38] Lin, C.M., Wu, F.M., Kim, H.K., Doyle, M.P., Michael, B.S. and Williams, L.K. (2003) A Comparison of Hand Washing Techniques to Remove Escherichia Coli and Caliciviruses under Natural or Artificial Fingernails. Journal of Food Protection, 66, 2296-2301.

[39] Edel, E., Houston, S., Kennedy, V. and LaRocco, M. (1998) Impact of a 5-Minute Scrub on the Microbial Flora Found on Artificial, Polished, or Natural Fingernails of Operating Room Personnel. Nursing Research, 47, 54-59. http://dx.doi.org/10.1097/00006199-199801000-00010

[40] Pottinger, J., Burns, S. and Manske, C. (1989) Bacterial Carriage by Artificial versus Natural Nails. American Journal of Infection Control, 17, 340-344. http://dx.doi.org/10.1016/0196-6553(89)90003-5

[41] Vanholder, R., Canaud, B., Fluck, R., Jadoul, M., Labriola, L., Mart-Monros, A., Tordoir, J. and Van Biesen, W. (2010) Diagnosis, Prevention and Treatment of Haemodialysis Catheter-Related Bloodstream Infections (CRBSI): A Position Statement of European Renal Best Practice (ERBP). NDT Plus, 3, 234-246. http://dx.doi.org/10.1093/ndtplus/sfq041

[42] Tordoir, J., Canaud, B., Haage, P., Konner, K., Basci, A., Fouque, D., Kooman, J., Martin-Malo, A., Pedrini, L., Pizzarelli, F., Tattersall, J., Vennegoor, M., Wanner, C., Wee, P. and Vanholder, R. (2007) EBPG on Vascular Access. Nephrology Dialysis Transplantation, 22, ii88-ii117. http://dx.doi.org/10.1093/ndt/gfm021

[43] ERA/EDTA Guidelines (2002) European Best Practice Guidelines for Haemodialysis (Part 1). Section VI: Haemodialysis-Associated Infection. Nephrology Dialysis Transplantation, 17, 73-87.

[44] National Kidney Foundation (2006) KDOQI Clinical Practice Guidelines and Clinical Practice Recommendations: 2006 Updates: Hemodialysis Adequacy, Peritoneal Dialysis Adequacy and Vascular Access. American Journal of Kidney Diseases, 48, S1-S322.

[45] National Kidney Foundation (2001) KDOQI Clinical Practice Guidelines for Vascular Access: Updates 2000. American Journal of Kidney Diseases, 37, S137-S181. http://dx.doi.org/10.1016/S0272-6386(01)70007-8

[46] Wiener-Well, Y., Galuty, M., Rudensky, B., Schlesinger, Y., Attias, D. and Yinnon, A.M. (2011) Nursing and Physician Attire as Possible Source Of Nosocomial Infections. American Journal of Infection Control, 39, 555-559. http://dx.doi.org/10.1016/j.ajic.2010.12.016

[47] Perry, C., Marshall, R. and Jones, E. (2001) Bacterial Contamination of Uniforms. Journal of Hospital Infection, 48, 238-241. http://dx.doi.org/10.1053/jhin.2001.0962

[48] Babb, J.R., Davies, J.G. and Ayliffe, G.A. (1983) Contamination of Protective Clothing and Nurses' Uniforms in an Isolation Ward. Journal of Hospital Infection, 4, 149-157. http://dx.doi.org/10.1016/0195-6701(83)90044-0

[49] Fijan, S. and Turk, S.S. (2012) Hospital Textiles, Are They a Possible Vehicle for Hospital-Associated Infection? International Journal of Environmental Research and Public Health, 9, 3330-3343. http://dx.doi.org/10.3390/ijerph9093330

[50] Wilson, J.A., Loveday, H.P., Hoffman, P.N. and Pratt, R.J. (2007) Uniform: An Evidence Review of the Microbiological Significance of Uniforms and Uniform Policy in the Prevention and Control of Healthcare-Associated Infections. Report to the Department of Health (England). Journal of Hospital Infection, 66, 301-307. http://dx.doi.org/10.1016/j.jhin.2007.03.026

[51] Jackson, R. and Cole, M. (2010) Healthcare Workers’ Uniforms: Roles, Types and Determining Policy. British Journal of Nursing, 19, 438-441. http://dx.doi.org/10.12968/bjon.2010.19.7.47445 
[52] Kramer, A., Schwebke, I. and Kampf, G. (2006) How Long Do Nosocomial Pathogens Persist on Inanimate Surfaces? A Systematic Review. BMC Infectious Diseases, 6, 130. http://www.biomedcentral.com/1471-2334/6/130 http://dx.doi.org/10.1186/1471-2334-6-130

[53] Dietze, B., Rath, A., Wendt, C. and Martiny, H. (2001) Survival of MRSA on Sterile Goods Packaging. Journal of Hospital Infection, 49, 255-261. http://dx.doi.org/10.1053/jhin.2001.1094

[54] Bond, W.W., Favero, M.S., Peterson, N.J., Gravell, C.R., Ebert, J.W. and Maynhard, J.E. (1981) Survival of Hepatitis B Virus after Drying and Storage for One Week. The Lancet, 1, 550-551. http://dx.doi.org/10.1016/S0140-6736(81)92877-4

[55] CDC (2016) Hepatitis C FAQs for the Public. www.cdc.gov/hepatitis/C/cFAQ.htm

[56] Ciesek, S., Friesland, M., Steinmann, J., Becker, B., Wedemeyer, H., Manns, M.P., Steinmann, J., Pietschmann, T. and Steinmann, E. (2010) How Stable Is the Hepatitis C Virus (HCV)? Environmental Stability of HCV and Its Susceptibility to Chemical Biocides. Journal of Infectious Diseases, 201, 1859-1866. http://dx.doi.org/10.1086/652803

[57] Barré-Sinoussi, F., Nugeyre, M.T. and Chermann, J.C. (1985) Resistance of AIDS Virus at Room Temperature. The Lancet, 11, 721-722. http://dx.doi.org/10.1016/S0140-6736(85)92955-1

[58] Tjotta, E., Hungnes, O. and Grinde, B. (1991) Survival of HIV-I: Activity after Disinfection, Temperature and pH Changes, or Drying. Journal of Medical Virology, 35, 223-227. http://dx.doi.org/10.1002/jmv.1890350402

[59] Cataňo, J.C., Echeverri, L.M. and Szela, C. (2012) Bacterial Contamination of Clothes and Environmental Items in a Third-Level Hospital in Colombia. Interdisciplinary Perspectives on Infectious Diseases, 2012, Article ID: 507640.

[60] Dancer, S.J. (2009) The Role of Environmental Cleaning in the Control of Hospital-Acquired Infection. Journal of Hospital Infection, 73, 378-385. http://dx.doi.org/10.1016/j.jhin.2009.03.030

[61] CDC (2008) Infection Control Requirements for Dialysis Facilities and Clarification Regarding Guidance on Parenteral Medication Vials. Morbidity and Mortality Weekly Report, 57, 875-876.

[62] Hoen, B., Paul-Dauphin, A., Hestin, D. and Kessler, M. (1998) EPIBACDIAL: A Multicenter Prospective Study of Risk Factors for Bacteremia in Chronic Haemodialysis Patients. Journal of the American Society of Nephrology, 9, 869-876.

[63] CDC/National Center for Emerging and Zoonotic Infectious Diseases, Division of Healthcare Quality Promotion. Haemodialysis Central Venous Catheter Scrub-the-Hub-Protocol. www.cdc.gov/dialysis/PDFs/collaborative/hemodialysis-central-venous-catheter-sth-protocol.pdf

[64] Salzman, M.B., Isenberg, H.D. and Rubin, J.G. (1993) Use of Disinfectants to Reduce Microbial Contamination of Hubs of Vascular Catheters. Journal of Clinical Microbiology, 31, 475-479.

[65] Hess, S. and Bren, V. (2013) Essential Components of an Infection Prevention Program for Outpatient Hemodialysis Centers. Seminars in Dialysis, 26, 384-398. http://dx.doi.org/10.1111/sdi.12102

[66] Garrick, R. and Morey, R. (2015) Dialysis Facility Safety: Processes and Opportunities. Seminars in Dialysis, 28, 514524. http://dx.doi.org/10.1111/sdi.12395

[67] Kapoian, T., Meyer, K.B. and Johnson, D.S. (2015) Infection Prevention and the Medical Director: Uncharted Territory. Clinical Journal of the American Society of Nephrology, 10, 863-874. http://dx.doi.org/10.2215/CJN.06050614

[68] CDC (2012) NHSN Dialysis Event Protocol. http://www.cdc.gov/nhsn/PDFs/pscManual/8pscDialysisEventcurrent.pdf

[69] De Ambrogi, M. (2016) The Simple Story of Clean Hands. The Lancet Infectious Diseases, 16, 903. http://dx.doi.org/10.1016/S1473-3099(16)30203-1

[70] CDC/National Center for Emerging and Zoonotic Infectious Diseases, Division of Healthcare Quality Promotion. Key Areas for Patient Education-Collaborative-Dialysis. www.cdc.gov/dialysis/prevention-tools/Key-areas-patient-education.html

[71] Miller, H.M., Tong, A., Tunnicliffe, D.J., Campbell, D., Pinter, J., Commons, R.J., Athane, E., Craig, J.C., Gilroy, N., Green, J., Henderson, B., Howell, M., Stuart, R.L., Van Eps, C., Wong, M.G., De Zoysa, J. and Jardine, M.J. (2016) Identifying and Integrating Patient and Caregiver Perspectives for Clinical Practice Guidelines on the Screening and Management of Infectious Microorganisms in Hemodialysis Units. Hemodialysis International, Online.

[72] Kidney International (2008) Kidney Disease: Improving Global Outcomes (KDIGO) Clinical Practice Guidelines for the Prevention, Diagnosis, Evaluation, and Treatment of Hepatitis C in Chronic Kidney Disease. Kidney International, 73, S1-S99. 


\section{Abbreviation Note List}

$\begin{array}{ll}\text { ABHR } & \text { Alcohol-Based Hand Rub } \\ \text { ARB } & \text { Access-Related Bloodstream Infection } \\ \text { AVF } & \text { Arteriovenous Fistula } \\ \text { AVG } & \text { Arteriovenous Graft } \\ \text { APIC } & \text { Association for Professionals in Infection Control and Epidemiology } \\ \text { BSI } & \text { Bloodstream Infection } \\ \text { CDC } & \text { Centers for Disease Control and Prevention } \\ \text { C. difficile } & \text { Clostridium Difficile } \\ \text { DHQP } & \text { Division of Healthcare Quality Promotion } \\ \text { EBPG/ERBP } & \text { European Best Practice Guidelines/European Renal Best Practice } \\ \text { HAIs } & \text { Healthcare-Associated Infections } \\ \text { HICPAC } & \text { Healthcare Infection Control Practices Advisory Committee } \\ \text { HCW } & \text { Healthcare Workers } \\ \text { HD } & \text { Hemodialysis } \\ \text { HBsAg } & \text { Hepatitis B Surface Antigen } \\ \text { HBV } & \text { Hepatitis B Virus } \\ \text { HCV } & \text { Hepatitis C Virus } \\ \text { HIV } & \text { Human Immunodeficiency Virus } \\ \text { KDOQI } & \text { Kidney Disease Outcomes Quality Initiative } \\ \text { LASI } & \text { Local Access Site Infection } \\ \text { MRSA } & \text { Methicillin-Resistant Staphylococcus Aureus } \\ \text { NAT } & \text { Nucleic Acid Amplification } \\ \text { NCEZID } & \text { National Center for Emerging and Zoonotic Infectious Diseases } \\ \text { NHSN } & \text { National Healthcare Safety Network } \\ \text { PPE } & \text { Personal Protective Equipment } \\ \text { VA } & \text { Vascular Access } \\ \text { VAI } & \text { Vascular Access Infection } \\ \text { VRE } & \text { Vancomycin-Resistant Enterococci } \\ \text { WHO } & \text { World Health Organization } \\ & \end{array}$

Submit or recommend next manuscript to OALib Journal and we will provide best service for you:

- Publication frequency: Monthly

- 9 subject areas of science, technology and medicine

- Fair and rigorous peer-review system

- Fast publication process

- Article promotion in various social networking sites (LinkedIn, Facebook, Twitter, etc.)

- Maximum dissemination of your research work

Submit Your Paper Online: Click Here to Submit

Contact Us: service@oalib.com 